\title{
一養豚場における新生豚の臍帯出血の集団発生例
}

（発生状況，臨床症状および血液検査所見）

渡辺一夫*・鈴木有紀子* $\cdot$ 堀北哲也 $*$. 山本輝次 $*$ 星 欽彌 $*$ 近藤寧子*

\section{An Outbreak of the Umbilical Cord Bleeding in New-Borne Pigs. (Occurrence Pattern, Clinical Symptoms and Hematological Examinations)}

\author{
Kazuo WATANABE*, Yukiko SUZUKI*, Tetuya HORIKITA*, Terutugu YAMAMOTO*, \\ Kinnji HOSHI* and Teiko KONDOU*
}

* Federation of Agricultural Mutual Aid Association in Chiba prefecuture,Japan

\begin{abstract}
Summary
An outbreak of the unusual type of umbilical cord (UC) bleeding, which caused a big economical loss, was observed in one farm in Chiba prefecture and its occurrence pattern, clinical symptoms and hematological data were examined. The farm had 350 breeding pigs and raised the new-borne pigs. Between June 1994 and February 1995, the UC bleeding was observed in 223 cases (40.8\%) of 547 parturitions and 83 new-borne pigs were died due to bleeding. Epidemiological investigation indicated that these bleedings were not due to hereditary or infectious causes. The new-borne pigs did not show any clinical symptoms. They had good contractions of the umbilical artery just after birth, however, the UC gradually became to be congested by blood and started bleeding at 1 hour and $34 \mathrm{~min}(+-45 \mathrm{~min})$ after their births. Thereafter, the congestions of UC were deteriorated and blood was leaked from both of cutting stumps and some injured parts of the UC. In the blood coagulation analysis, number of blood platelet, bleeding time, coagulating time, APT and PT were all within the normal levels, however, decreased level of fibrinogen was detected. No major abnormalities were observed in pathological examinations. Based on the above examinations, these UC bleeding symptoms were suspected to be caused by incomplete blood coagulations due to the decreased level of fibrinogen in the fetus.
\end{abstract}

要 約

一般的に見られる湾带出血とは異なる症状の新生 豚の臍帯出血が，管内の一農場で集団的に認められ， 大きな被害を及ぼしたので，その発生状況，臨床症 状および血液検查所見について検討した。発生農場 は, 管内で繁殖雌豚350頭飼養している一貫経営の養

\footnotetext{
*千葉県農業共済組合連合会, 北部家畜診療所 于289-04 香取郡山田町仁良字牧野99-1
}

豚場であり，1994年 6 月から1995年 2 月までに, 547 腹中 223 腹 $(40.8 \%)$ に湾帯出血が認められ，83頭の 新生豚が出血死した。疫学調査の結果から, 遺伝性 疾患や感染症が原因とは考之られなかった。新生豚 は, 出生直後は臨床的に異常は認められず，湾動脈 の収縮も良好であった。しかし，次第に臍帯の腹側 端から膻带が充血し, 出生後 1 時間 34 分土45分で湾 帯の断端から出血を認めた。その後，さらに充血が 進行し䏸帯は膨らみ，断端のみならず娈帯の損傷部 
からも血液が漏出するようになった。血液凝固能検 植では血小板, 出血時間, 凝固時間, APTT, およ びPTは正常であったが, フィブリノーゲンの減少 が認められた。また, 病理学検査ではなんら異常は 認められなかった。以上のことから，本症の直接の 原因は，胎児期のフィブリノーゲンの不足による血 液凝固不全であると思われた。

\section{I. 序 文}

新生豚の亪帯出血は，どの養豚場でも散発的に認 カられ，そのほとんどは, 湾帯が腹側の近位で断列 し恋動脈の収縮が不完全の場合に起こる。また，ま れに自家配合飼料給与農家でビタミン $\mathrm{K}$ の欠乏によ

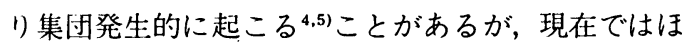
とんど観察されない。ところが, 生後 1 時間半程度 経過してから，臍帯出血を起こす新生豚が北部家亩 診㙩所管内の一農場で集団的に認められ, 多くの新 生豚が出血死した。このように，一般的に見られる 撙带出血とは異なる症:状の湾带出血の集団発生例に ついて, 発生状況, 臨床症状および血液検查所見等 を検討した。

\section{II. 材料および方法}

発生農場は管内で繁殖雌豚350頭飼養している一 貫経営のM養豚場であり, 繁殖䧳豚は LW 種, 繁殖 雄豚はD種を用いている。

調查期間は1994年 6 月から1995年 2 月までである。

発生状況調査には繁殖䧳豚延べ547頭の分婏管理 カードを用いた。
臨床症状は新生豚30頭について観察した。 血液凝固能検查は血小板数 (簡易法), 出血時間 (Duke 法), 凝固時間 (Lee-White 法)，フィブリ) ーゲン(熱沈殿屈折計法, チロジン法), 活性化部分 トロンボプラスチン時間(APTT), プロトロンビン 時間（PT），およU゙第X III因子の定量について新生 豚29頭(合計)に実施した。なお，APTT，PTおよ び第XIII因子については東京大学農学部獣医内科に 依頼した。

病理学検査は, 新生豚 10 頭 (生存 2 頭, 死亡 8 頭) について実施した。なお，検査は農林水産省家甶衛 生試験場病理診断研究室に依頼して行った。

\section{III. 成 綘}

\section{1. 発生状況}

547 腹中 223 腹, $40.8 \%$ に臍带出血が認められ, 83 頭の新生豚が出血死した。この養豚場は毎月60腹前 後分婏していた。月別の腹毎の臍帯出血の発生率(図 1 ）は，94年は夏に向かって増加し，9月が $50 \%$ と ピークとなり，その後次第に減少した。しかし，95 年の 2 月には急増し $61.2 \%$ となった。また，臍带出 秥を認めた腹は, 出血の程度は異なるものの同腹豚 のほとんどが発症した。

産次別の出現率（図 2 ）では，5産までの発生率 が40\%前後であり， 6 産以降は出現率が乱高下して いた。しかし，産次構成比をみると， 5 産までは 15 \%前後で推移しているのに対し， 6 産以降は著しく 減少していた。したがって, 発生率と産次構成比と の関連から, 特に産次によって発生の偏りは認めら

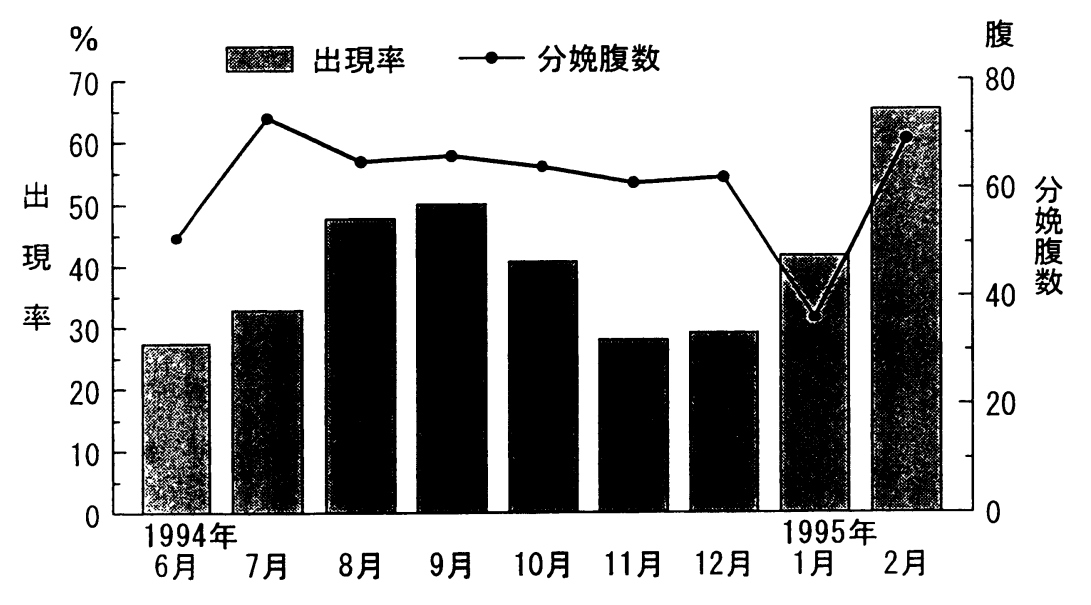

図 1 臍帯出血出現率 (月別・腹単位) 
れなかった。

分娩舎は， 1 4 室までが，コンクリート床にオ ガクズを撒いて使用しており，5室は，分婏庑房が 高床式で床材にテンダーコートを使用していた。分 婏室別の出現率（図 3 ）は，1４室が50\%前後で あるのに対し， 5 室が $15.6 \%$ と顕著に低下していた。

2 . 疫学調査

臍带出血は一昨年から見られるようになった。し かし, この養豚場の周辺地域での発生は, 認められ ていない。この養豚場に飼養されている繁殖雌豚は， 半数以上が大手種豚メーカーから購入したもので, 周辺地域でも多数飼育されていた。繁殖雄豚は自家 育成がほとんどであるが, 外部導入した繁殖雄豚や
購入精液による人工授精によって生まれた子睋にも 発生が認められた。また, 飼料や飼料添加郕は多く の養豚場で飼養されているものであった。

\section{3 . 症状}

臍带出血の状態を個体毎に時間を追って観察した。 出生直後では臍帯に異常は認められなかった。生 後30分では臍帯の起始部に軽度の充血が認められた。 生後 2 時間では充血が顕著となり, 恋帯の断端から 僅かに出血が認められた。生後 3 時間では湾帯の断 端から血液が滴下寸るようになった。また，湾帯を 自分で踏んだり，同腹豚に踏まれてできた損傷部か らも多く出血した。出生後 3 時間を経過すると，床 が血液で赤くなるほど出血した。したがって，発見

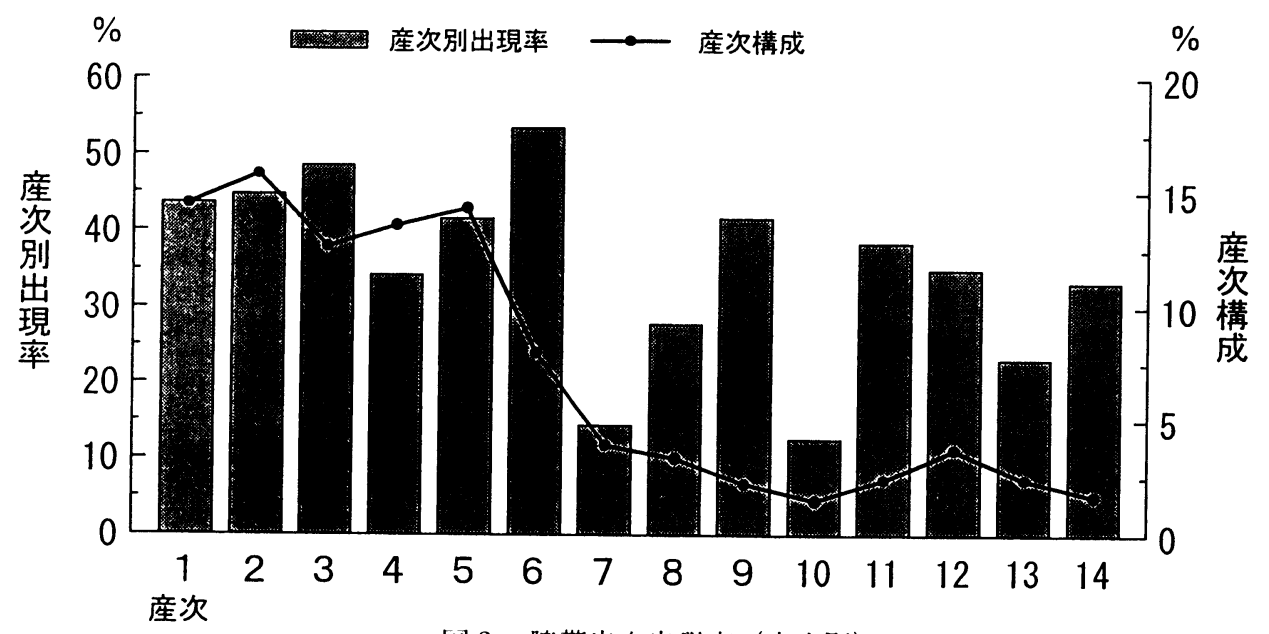

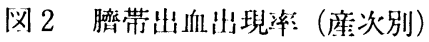

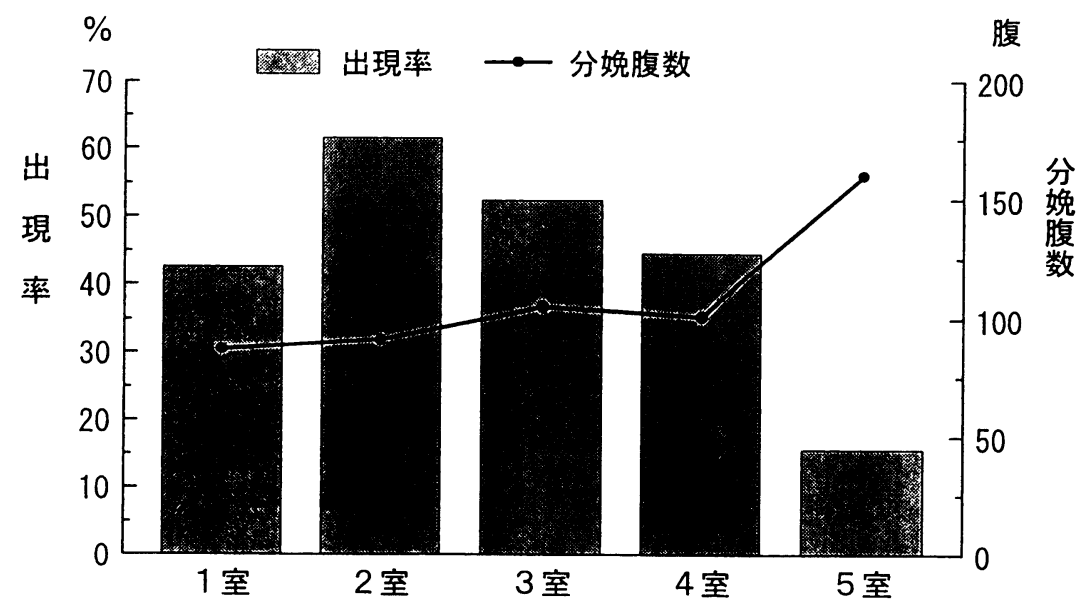

図 3 湾带出血出現率 (分娩室別) 
が達れると, 同腹豚の多くが出血死してしまうが, 早期に恋帯を結紮すれば出血を防止でき, 子豚の発 育も順調であった。

\section{4. 血液凝固能検查}

脺帯から血液が滴下するまでの時間を40頭の新生 豚について出生直後から計測したところ, 出血は生 後 1 時間半から 2 時間の間に集中していた（図 4 )。 出血時間の延長は認められず,赤血球100個当たり の血小板数も正常值の範囲内であった（図 4$)$ 。

血液凝固時間とフィブリノーゲン（熱沈殿屈折計 法)を出生直後と 1 週踣で測定した（図 5 )。血液凝 固時間の測定は出生直後では, 全例とも血液が完全 に凝固せず，一部フィブリン塊ができたのみであっ た。このため, 凝固が僅かでも認められた時間を記 録した。1 週齢になるとすべて完全に凝固した。い ずれも，凝固時間の顕著な延長は認められなかった。 フィブリノーゲンは 0 以下がいずれも半数以上に認 められた。

次に典型的な湾帯出血を起こした新生豚 2 頭を用 い血液凝固系について更に詳しく検査した（表 1 ）。 その結果, 出血時間は正常範囲内であった。また, 活性化部分トロンボプラスチン時間 (APTT) とプ ロトロンビン時間（PT）の延長は認められなかっ た。第XIII因子は $25 ， 38 \%$ といずれも $50 \%$ を下回り， フィブリノーゲンも低值を示した。

5 . 病理組織所見

出血死した新生豚10頭の病理組織所見は共通し, 臍帯や臟器の異常そして感染症を疑う所見は認めら

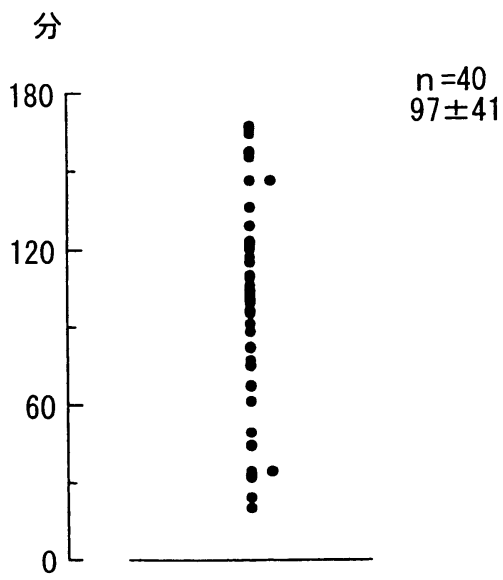

図 4 出生から臍帯出血に要した時間
れなかった（表 2$) 。$

\section{IV. 考 察}

疫学調査の結果から, 周辺地域での発生がないこ と，遺伝との関連は認められなかったことから，発 生原因として遺伝性疾患や感染症は考之られなかっ た。これは，娈帯を出生直後に結紮すれば正常に発 育すること，そして，病理組織所見に異常が認めら れないことからも明らかである。また，飼料および 飼料添加剤との関連も認められなかった。したがっ

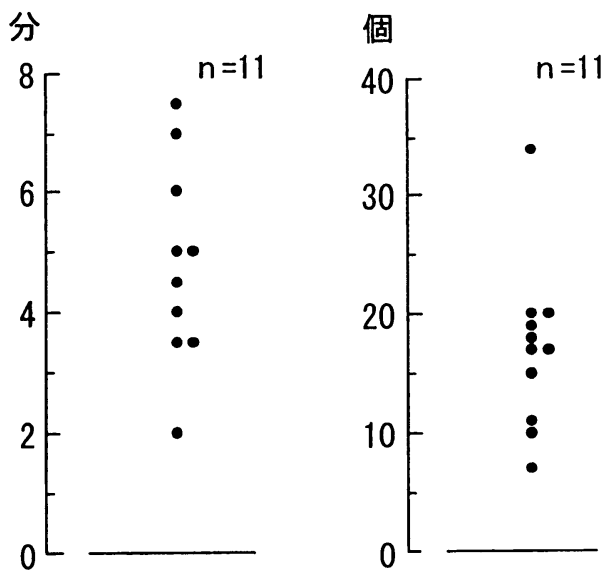

図 5 出血時間と血小板数（赤血球 100 個当たり）

表 1 血液検查

\begin{tabular}{lll}
\hline 項目/個体 & \multicolumn{1}{c}{$\mathrm{A}$} & \multicolumn{1}{c}{$\mathrm{B}$} \\
\hline 出血時間 & 3 分30秒 & 2 分30秒 \\
$\mathrm{APT} \mathrm{T}$ & 13.53 秒 & 7.3 秒 \\
$\mathrm{P} \mathrm{T}$ & 11.07 秒 & 6.47 秒 \\
第XIII因子 & $25 \%$ & $38 \%$ \\
フィブリノーゲン & $58 \mathrm{mg} / \mathrm{dl}$ & $46 \mathrm{mg} / \mathrm{dl}$ \\
\hline
\end{tabular}

表 2 病理組織所見

\begin{tabular}{|c|c|c|c|}
\hline 臓 器 & 所 見 & 臓 器 & 所 見 \\
\hline 肝 & グリコーゲン変性 & 胃 & 著変無し \\
\hline 脾 & 随外造血 & 空腸，回腸，結腸 & 著変無し \\
\hline 腎 & 著変無し & 骨格筋 & 著変無し \\
\hline 心 & 著変無し & 脳 & 著変無し \\
\hline 肺 & 著変無し & 骨髄 & 著変無し \\
\hline 胸腺, 唾液腺 & 著変無し & 臍帯 & 著変無し \\
\hline 副腎,下垂体 & 著変無し & & \\
\hline
\end{tabular}




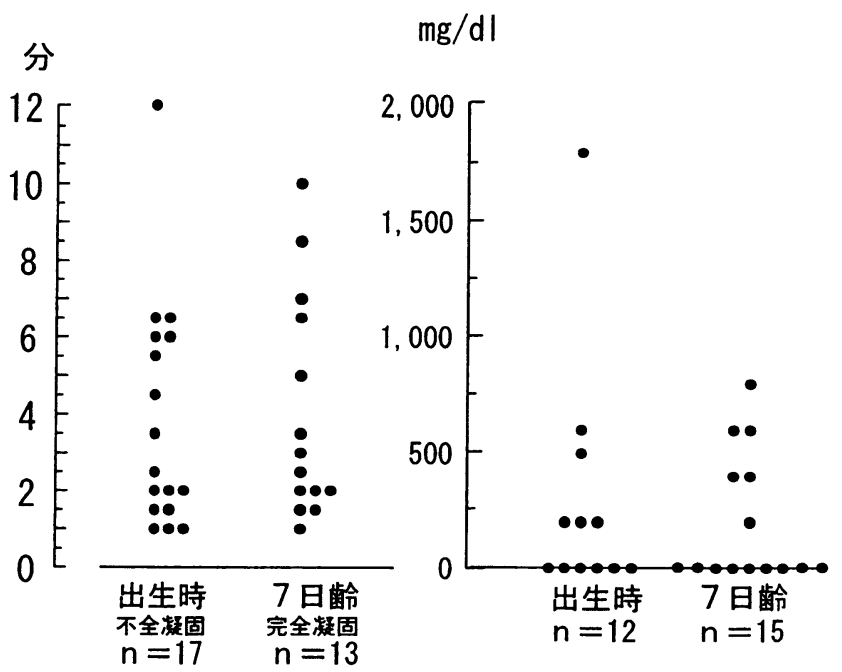

図 6 血液凝固時間とフィブリノーゲン

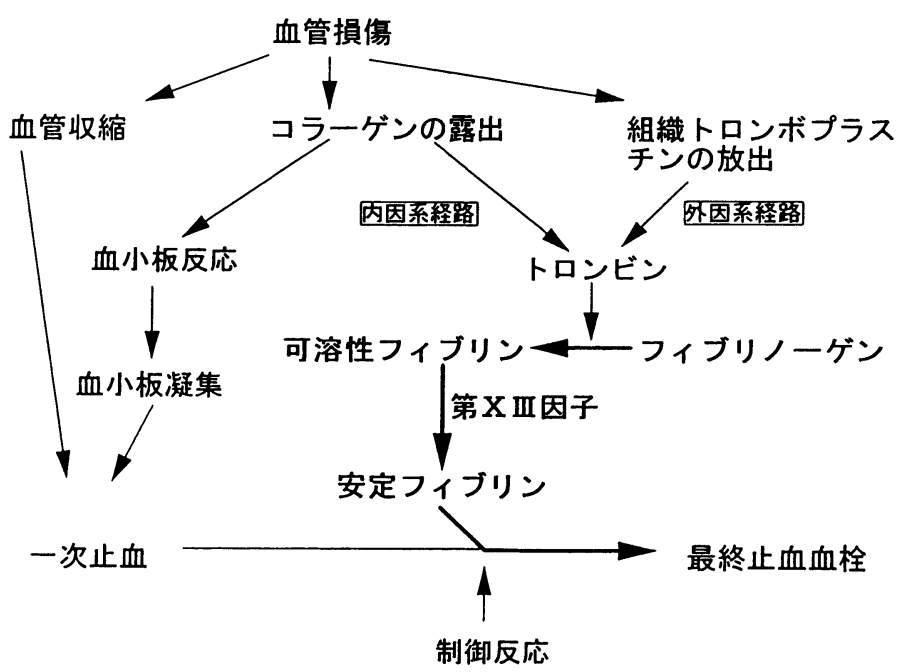

図 7 正常止血機構の相互関係

て，発生原因としては当養豚場独自の，環境性や栄 養性の因子が関与していると思われた。

正常止血機構の相互関係 ${ }^{3}$ を図 7 に示した。血液 凝固能唡査結果, 出血時間と血小板数は正常值の範

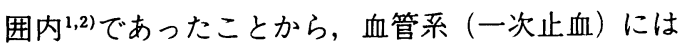
異常の無いことが判った。また, APTTは内因系,

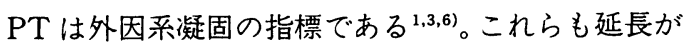
認められなかったことから，内外凝固系には異常は 認められなかった。第X III因子は七トでは正常値が $100 \pm 20 \%$ である。ブタではヒトより值は低いとされ
ている1'が，ブタでは正常值としてのデータは無い ので, 現在のところ検査值が異常値かどうか判断不 能であった。ただし，止血には第X III因子は $2 \sim 10$ \%あれば十分であるとのことから"第XIII因子の欠

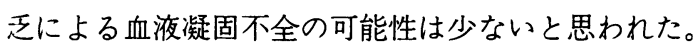
ところが, フィブリノーゲンは, 正常值が100 500 $\mathrm{mg} / \mathrm{dl}$ である2)のに対し明らかな低值を示した。し たがって, 臍帯出血の原因は, フィブリノーゲン不 足のために，止血に必要な安定したフィブリンのネ ットが十分に構築されないことから生じる, 血液凝 
固不全であると思われた。フィブリノーゲン欠乏に よる血液凝固異常は von Willebrand 病1)があるが, これは常染色体異常による遺伝性疾患なので本症と 異なると考えられた。また，フィブリノーゲンは肝 細胞で合成さ, 重度の肝疾患(慢性肝炎や肝硬変)

で減少する7)。しかし, 胎児期に重度の肝障害陥って いる可能性は示唆されなかった。すなわち, 何らか の原因で, 胎児の肝蔵におけるフィブリノーゲン合 成の抑制が示唆されたが，今後さらに本章の原因を 詳細に究明していかなければならないと考えられた。 分婏室の構造による発生率の違いは, オガクズが 大きな原因となっていると思われる。すなわち，充 血した湾帯にオガクズが付着すると，オガクズの吸 湿作用により充血が促進される。また，オガクズが 付着することによって娈带が損傷を受けやすくなる ことが考えられる。このようにオガクズの介在によ って臍带出血が促進されることが推測され，分娩室 の構造が本䞍:の発生摔に大きく影響することが示唆 された。

本症における対策の主は出生直後に臍帯を結禁す ることであるが臍帯を出血直後に結禁するためには, 夜間の連続的な分娩管理が必要になることから, 蓄 主に対して大きな負担がかる。現在これらの負担 を軽減するために, 夜間分婏を回避する目的で分婏 誘発と分娩延長による分婏コントロールの実施を進 めている。また, テンダーコートの豚房では発生が 少ないことから，分婏舎の改築も同時に計画中であ
る。

おわりに, 病理組織検査をしていただいた家畜衛 生試験場病理診断研究室長久保正法先生および東京 大学農学部獣医内科亘敏広先生に深謝いたします。

\section{文 献}

1 ) DODDS, W.J.: Clinical Biochemistry of Domestic Animals, 3rd ed.,741 794, Academic Press, Inc., New York (1980)：家畜臨床生化 学 (久保周一郎笽訳) 近代出版, 東京 (1983)。

2 ) 新山雅美: 豚病学, 熊谷哲夫ら編, 第三版, 598 606, 近代出版, 東京 (1987)。

3 ) 農林水産省経済局編: 臨床病理検査要領, 1987 年改定, $105 \sim 107,116 \sim 118,377 \sim 380$, 全国 農業共済協会, 東京(1987)。

4 ) SASAKI, Y. :Jpn. J.Vet.Sci., 44,933 940 (1982)。

5 ) SASAKI,Y.:Jpn. J.Vet.Sci., 47, 435〜 442 (1985)。

6) 沢田ノブ：検査データのよみ方・考之方, 酒井 望ら編, 第 7 版, 124 , 宇宙堂八木書店, 東京 (1984)。

7 ）山田外春：検査データのよみ方・考之方, 酒井 望ら編, 第 7 版, 132 , 宇宙堂八木書店, 東京 (1984)。 